Supporting Information

\title{
Biomass based sustainable Ammonia production: Digestion vs Gasification
}

\author{
Antonio Sáncheza, Mariano Martína1, Pastora Vegab \\ aDepartment of Chemical Engineering. University of Salamanca. Plz. Caídos 1-5. 37008. \\ Salamanca (Spain) \\ bDepartment of Computer Science. University of Salamanca. Plz. Caídos 1-5. 37008. Salamanca \\ (Spain) \\ Total number of pages: 21 \\ Total number of figures: 2 \\ Total number of tables: 8
}

\footnotetext{
${ }^{1}$ Corresponding author. Tel.: +34 923294479
}

Email address: mariano.m3@usal.es 


\section{Process model}

The modelling issues of the different unit involved in the process have been described in this section.

\subsection{Gasification}

Three gasification alternatives have been considered: indirect gasification, direct gasification with oxygen/steam and direct gasification with air/steam (see Figure 2).

\subsubsection{Indirect gasification}

Indirect gasification (Figure 2-A) consists of two chambers: one to gasify the biomass using steam as gasifying agent and the other one to burn the char produced during the biomass gasification to generate the heat necessary for the gasification of the biomass. Olivine is the solid used as heat transfer agent between the two chambers. The pressure in the gasifier is fixed to 1.6 bar $^{1}$. The ratios between steam and dry biomass and olivine and dry biomass are taken from Phillips et al..$^{2}$ and are equal to $0.4 \mathrm{~kg} \mathrm{steam} / \mathrm{kg}$ dry biomass and $27 \mathrm{~kg}$ olivine $/ \mathrm{kg}$ dry biomass, respectively.

To determine the outlet gas flow and its composition, the experimental correlations and methodology proposed by Phillips et al. ${ }^{2}$ have been considered. The temperature range for the correlation is $966-1287$ $\mathrm{K}$. The equation for each variable $(\mathrm{X})$ collected in Table $\mathrm{S} 1$ is as follow:

$$
X=a+b T+c T^{2}
$$

Where $\mathrm{T}$ is the temperature in ${ }^{\circ} \mathrm{F}$.

Table S1: Correlations for modelling the indirect gasification ${ }^{2}$

\begin{tabular}{|c|c|c|c|c|}
\hline $\mathrm{X}$ & $\mathrm{a}$ & $\mathrm{b}$ & $\mathrm{c}$ & Units \\
\hline Dry Syngas & 28.993 & -0.043325 & 0.000020966 & scf gas/ lb maf wood \\
\hline $\mathrm{CO}$ & 133.46 & -0.1029 & 0.000028792 & $\%$ mol dry gas \\
\hline $\mathrm{CO}_{2}$ & -9.5251 & 0.037889 & -0.000014927 & $\%$ mol dry gas \\
\hline $\mathrm{CH}_{4}$ & -13.82 & 0.044179 & -0.000046467 & $\%$ mol dry gas \\
\hline $\mathrm{C}_{2} \mathrm{H}_{4}$ & -38.258 & 0.058435 & -0.000019868 & $\%$ mol dry gas \\
\hline $\mathrm{C}_{2} \mathrm{H}_{6}$ & 11.114 & -0.011667 & 0.000003064 & $\%$ mol dry gas \\
\hline $\mathrm{H}_{2}$ & 17.996 & -0.026448 & 0.00001893 & $\%$ mol dry gas \\
\hline $\mathrm{C}_{2} \mathrm{H}_{2}$ & -4.3114 & 0.0054499 & -0.000001561 & $\%$ mol dry gas \\
\hline Tar & 0.045494 & -0.000019759 & 0 & Ib/lb dry wood \\
\hline
\end{tabular}


The amount of oxygen, sulphur and nitrogen in the char is fixed to $4 \%, 8.3 \%$ and $6.6 \%$ with respect to the original component in the inlet biomass. The mass balances complete the equations to describe the gasifier operation.

The stream exiting the gasifier contains the gases generated, char, ash from biomass and olivine. In the cyclone, solid components are separated with an efficiency of $99.99 \%$. These are sent to the combustor while the gas continues to the cleaning stages.

In the combustor, the char is burnt with air. An excess of air of $20 \%$ is assumed and this air is preheat before being introduced in the combustor up to $473 \mathrm{~K}^{3}$ Mass and energy balances are used to compute the composition of the leaving gases and their final temperature. Total combustion of the char is assumed. A specific heat of combustion for char of $25000 \mathrm{~kJ} / \mathrm{kg}$ is taken 4 . Olivine is added to the combustor to replace the small solid amount dragged by the gases. The particles leaving with the outlet gases from the combustor are removed and cooled down to ambient temperature before they are released.

\subsubsection{Direct gasification with $\mathrm{O}_{2} /$ Steam}

Direct gasification (Figure 2-B) uses only one chamber to carry out the gasification process. To model the gasifier performance, the correlation from Dutta \& Phillips ${ }^{5}$ are used. The correlation is of the form:

$$
f_{i}=A+B \cdot P+C \cdot T+D \cdot\left(\frac{\mathrm{O}_{2}}{\text { Feed } C}\right)+E \cdot\left(\frac{\mathrm{H}_{2} \mathrm{O}}{\text { Feed } \mathrm{C}}\right)
$$

Where $\mathrm{f}_{\mathrm{i}}$ is the molar ratio for each component according to Table $3, \mathrm{P}$ is the gasifier pressure in psi, $\mathrm{T}$ is the temperature in ${ }^{\circ} \mathrm{F},\left(\mathrm{O}_{2} /\right.$ Feed $\left.\mathrm{C}\right)$ is the molar ratio between fed oxygen and the inlet carbon in the biomass and $\left(\mathrm{H}_{2} \mathrm{O} /\right.$ Feed $\left.\mathrm{C}\right)$ is the molar ratio between inlet steam and the inlet carbon in the biomass. The coefficients for the equation are collected in Table S2. 
Table S2: Correlations to describe the behaviour of $\mathrm{O}_{2} /$ Steam direct gasification ${ }^{5}$

\begin{tabular}{|c|c|c|c|c|c|}
\hline Molar ratio $\left(\mathrm{f}_{\mathrm{i}}\right)$ & $\mathrm{A}$ & $\mathrm{B}$ & $\mathrm{C}$ & $\mathrm{D}$ & $\mathrm{E}$ \\
\hline $\mathrm{H}_{2} /$ Feed H & $-3.830761 \mathrm{E}-1$ & $1.894350 \mathrm{E}-4$ & $2.666675 \mathrm{E}-4$ & $1.060088 \mathrm{E}-1$ & $7.880955 \mathrm{E}-2$ \\
\hline $\mathrm{CO}_{\mathrm{C}}$ Feed C & $-8.310017 \mathrm{E}-2$ & $-3.340050 \mathrm{E}-4$ & $2.614482 \mathrm{E}-4$ & $1.495730 \mathrm{E}-1$ & $-5.268367 \mathrm{E}-2$ \\
\hline $\mathrm{CO}_{2} /$ Feed C & $7.157172 \mathrm{E}-2$ & $3.843454 \mathrm{E}-4$ & $1.286060 \mathrm{E}-5$ & $6.124545 \mathrm{E}-1$ & $9.980868 \mathrm{E}-2$ \\
\hline $\mathrm{CH}_{4} /$ Feed C & $1.093589 \mathrm{E}-2$ & $1.388446 \mathrm{E}-4$ & $8.812765 \mathrm{E}-5$ & $-2.274854 \mathrm{E}-1$ & $3.427825 \mathrm{E}-2$ \\
\hline $\mathrm{C}_{2} \mathrm{H}_{4} /$ Feed C & $5.301812 \mathrm{E}-2$ & $-6.740399 \mathrm{E}-5$ & $-1.372749 \mathrm{E}-5$ & $-9.076286 \mathrm{E}-3$ & $-4.854082 \mathrm{E}-3$ \\
\hline $\mathrm{C}_{2} \mathrm{H}_{6} /$ Feed C & $1.029750 \mathrm{E}-1$ & $-5.440777 \mathrm{E}-6$ & $-5.350103 \mathrm{E}-5$ & $-3.377091 \mathrm{E}-2$ & $-1.915339 \mathrm{E}-3$ \\
\hline $\mathrm{C}_{6} \mathrm{H}_{6} /$ Feed C & $4.676833 \mathrm{E}-2$ & $-1.937444 \mathrm{E}-5$ & $-1.270868 \mathrm{E}-5$ & $-1.046762 \mathrm{E}-2$ & $-8.459647 \mathrm{E}-3$ \\
\hline $\mathrm{C}_{10} \mathrm{H}_{8} /$ Feed C & $1.827359 \mathrm{E}-2$ & $-2.328921 \mathrm{E}-6$ & $-5.951746 \mathrm{E}-6$ & $-1.936385 \mathrm{E}-2$ & $-7.678310 \mathrm{E}-4$ \\
\hline & & & & & 0.00 \\
\hline Char & 3.36 & 0.00 & 0.00 & 0.00 & 0.00 \\
\hline $\begin{array}{c}\% \text { Feed N in } \\
\text { Char }\end{array}$ & 8.45 & 0.00 & 0.00 & 0.00 & 0.3332 \\
\hline $\begin{array}{c}\text { \%Feed S in } \\
\text { Char }\end{array}$ & 1.512040 & $1.582010 \mathrm{E}-4$ & $-6.972612 \mathrm{E}-4$ & $1.573581 \mathrm{E}-1$ & \\
\hline $\begin{array}{c}\text { \%Feed O in } \\
\text { Char }\end{array}$ & & & & & \\
\hline
\end{tabular}

The temperature range for the correlation is between $1027-1255 \mathrm{~K}$ and for pressures between $5.75-23.75$ bar. The ratio oxygen/inlet carbon must be in the range of $0.148-0.343$ and the ratio steam/inlet carbon between $0.24-1.975$. The gases leaving the gasifier are cleaned from solids in two cyclones, the first one to remove the char and the second one to remove the ashes 1 .

\subsubsection{Direct gasification with Air/Steam}

The direct gasifier with air and steam uses a configuration similar to the direct gasifier with oxygen/steam. However, the oxygen is replaced by air or an enriched air with up to an oxygen molar fraction of 0.4 . A surrogate model based on correlations has been developed in this work. The data for these correlations have been taken from the experiments carried out in a gasification pilot plant 6,7 . The data used to develop the correlations employed wood pellets as raw material with an empirical formula of $\mathrm{CH}_{1.4} \mathrm{O}_{0.64}$ (dry and ash free) calculated based on the ultimate analysis of the biomass. The gasifier operated adiabatically. The working pressure was atmospheric. With these data, the yield $\left(\mathrm{Y}_{\mathrm{i}}\right)$ for $\mathrm{H}_{2}, \mathrm{CO}, \mathrm{CO}_{2}, \mathrm{CH}_{4}$ and Char was correlated as a function of four variables: the Gasifier Temperature $(T)$, the Steam to Biomass ratio $(S / B)$ defined as the mass ratio between the inlet steam flow and the fed biomass (dry and ash free), the oxygen 
percentage of the enriched air (OP) and the equivalent ratio (ER) defined as the mass ratio between the real inlet oxygen respect to the stoichiometric oxygen required for combustion. This data has been fitted to the following equation:

$$
Y_{i}=a_{0}+a_{1} T+a_{2} T^{2}+a_{3} E R+a_{4} E R^{2}+a_{5}(S / B)+a_{6}(S / B)^{2}+a_{7} O P+a_{8} O P^{2}
$$

Where $Y_{i}$ is the yield as $\mathrm{g} / \mathrm{kg}$ dry and ash free (daf) biomass and $\mathrm{T}$ the temperature in $\mathrm{K}$. The Table $\mathrm{S} 3$ collects the coefficient for the equation eq.(S3). The correlations have been obtained for the following ranges for the variables: ER, 0.19-0.38, OP, 0.21-0.4, S/B, 0-0.63, T, 1000-1113 K.

Table S3: Correlations to model the Air/Steam direct gasifier.

\begin{tabular}{|c|c|c|c|c|c|}
\hline & $\mathrm{H}_{2}$ & $\mathrm{CO}$ & $\mathrm{CO}_{2}$ & $\mathrm{CH}_{4}$ & Char \\
\hline $\mathrm{a}_{0}$ & 236.134724 & -758.768571 & 36651.3912 & 1625.70807 & 1356.79816 \\
\hline $\mathrm{a}_{1}$ & -0.59246955 & 2.87931869 & -91.0013798 & -3.92738663 & -3.60847944 \\
\hline $\mathrm{a}_{2}$ & 0.00035217 & -0.00197877 & 0.0593536 & 0.00251846 & 0.00230493 \\
\hline $\mathrm{a}_{3}$ & 168.079598 & -9.99925439 & -6141.40211 & -141.574346 & 549.840001 \\
\hline $\mathrm{a}_{4}$ & -257.915778 & 817.985898 & 11151.9862 & 210.792784 & -1090.38656 \\
\hline $\mathrm{a}_{5}$ & 37.8323438 & -103.235783 & 319.997157 & -31.419258 & -30.0839584 \\
\hline $\mathrm{a}_{6}$ & -31.9242057 & -258.958857 & 345.997303 & 50.18269 & -1.1476191 \\
\hline $\mathrm{a}_{7}$ & 3.70003089 & 380.503236 & -1752.95314 & 63.8403192 & 214.600153 \\
\hline $\mathrm{a}_{8}$ & 44.4015283 & 215.128344 & -1008.99174 & -133.133672 & 42.8805991 \\
\hline
\end{tabular}

Due to the very similar composition between switchgrass and the wood pellets and the fact that a thermochemical process is carried out, it is assumed that the same yields will be achieved if switchgrass is employed instead of the wood pellets.

The following mass balances describe the gasifier performance. The tars composition $\left(\mathrm{C}_{6} \mathrm{H}_{6} \mathrm{O}_{2}\right)$ is taken from Thunman et al. ${ }^{8}$. The gasifier is modelled using eq.(S4)-eq.(S18) including yield calculations (computed using the correlation eq.(S3)), mass balances and some empirical parameters.

$$
\begin{gathered}
\text { Biomass }+\mathrm{O}_{2}+\mathrm{N}_{2}+\mathrm{H}_{2} \mathrm{O} \rightarrow \mathrm{H}_{2}+\mathrm{CO}+\mathrm{CO}_{2}+\mathrm{CH}_{4}+\mathrm{N}_{2}+\mathrm{O}_{2}+\mathrm{C}_{6} \mathrm{H}_{6} \mathrm{O}_{2}+\text { Char } \\
f c_{i}^{\text {out }}=Y_{i} \cdot f c_{\text {biomass daf }}^{\text {in }} \cdot \frac{M W_{\text {biomass daf }}}{M W_{i} \cdot 1000} \quad \forall i=\left\{\mathrm{H}_{2}, \mathrm{CO}, \mathrm{CO}_{2}, \mathrm{CH}_{4}\right\} \\
Y_{\text {char }} \cdot f c_{\text {biomass daf }}^{\text {in }} \cdot \frac{M W_{\text {biomass daf }}}{1000}=\sum_{j} n_{j}^{\text {char }} M W_{j} \quad \forall j=\{C, H, O, N, S\}
\end{gathered}
$$




$$
\begin{aligned}
& f_{\text {biomass daf }}^{\text {in }} \cdot C_{\text {biomass daf }}=f c_{\mathrm{CO}_{2}}^{\text {out }}+f c_{C O}^{\text {out }}+f c_{C_{4}}^{\text {out }}+n_{C}^{\text {char }}+6 \cdot f c_{\text {Tars }}^{\text {out }} \\
& 2 \cdot f c_{\mathrm{H}_{2} \mathrm{O}}^{\text {in }}+f c_{\text {biomass daf }}^{\text {in }} \cdot H_{\text {biomass daf }}=2 \cdot f c_{\mathrm{H}_{2}}^{\text {out }}+2 \cdot f c_{\mathrm{H}_{2} \mathrm{O}}^{\text {out }}+4 \cdot f c_{\mathrm{CH}_{4}}^{\text {out }}+6 \cdot f c_{\text {Tars }}^{\text {out }}+2 \cdot f c_{\mathrm{H}_{2} \mathrm{~S}}^{\text {out }}+3 \cdot f c_{\mathrm{NH}_{3}}^{\text {out }}+n_{\mathrm{H}}^{\text {char }} \\
& f c_{\mathrm{H}_{2} \mathrm{O}}^{\text {in }}+f c_{\text {biomass daf }}^{\text {in }} \cdot O_{\text {biomass daf }}+2 \cdot f c_{\mathrm{O}_{2}}^{\text {in }}=f c_{\mathrm{CO}}^{\text {out }}+2 \cdot f c_{\mathrm{CO}_{2}}^{\text {out }}+f c_{\mathrm{H}_{2} \mathrm{O}}^{\text {out }}+n_{\mathrm{O}}^{\text {char }}+2 \cdot f c_{\text {Tars }}^{\text {out }}+2 \cdot f c_{\mathrm{O}_{2}}^{\text {out }} \\
& f c_{N_{2}}^{\text {in }}=f c_{N_{2}}^{\text {out }} \\
& f c_{a s h}^{\text {in }}=f c_{\text {ash }}^{\text {out }} \\
& f c_{\text {biomass daf }}^{\text {in }} \cdot S_{\text {biomass daf }}=f c_{\mathrm{H}_{2} \mathrm{~S}}^{\text {out }}+n_{S}^{\text {char }} \\
& f c_{\text {biomass daf }}^{\text {in }} \cdot N_{\text {biomass }}+2 \cdot f c_{N_{2}}^{\text {in }}=f c_{N_{3}}^{\text {out }}+2 \cdot f c_{N_{2}}^{\text {out }}+n_{N}^{\text {char }} \\
& X_{\text {carbon }}=\frac{f_{\text {biomass daf }}^{\text {in }}-n_{C}^{\text {char }}}{f c_{\text {biomassdaf }}^{\text {in }}} \\
& 0.87 \leq X_{\text {carbon }} \leq 0.98 \\
& n_{O}^{\text {char }}=\frac{5}{100} \cdot f c_{\text {biomass daf }}^{\text {in }} \cdot O_{\text {biomass daf }} \\
& n_{N}^{\text {char }}=\frac{3.36}{100} \cdot f c_{\text {biomass daf }}^{\text {in }} \cdot N_{\text {biomass daf }} \\
& n_{S}^{\text {char }}=\frac{8.45}{100} \cdot f c_{\text {biomass daf }}^{\text {in }} \cdot S_{\text {biomass daf }}
\end{aligned}
$$

Where $f c_{i}$ is the inlet or outlet molar flow for component $\mathrm{i}, Y_{i}$ is the yield of component $\mathrm{i}$ calculated using the equation eq.(S3), $M W_{i}$ is the molecular weight for each component, $X_{\text {carbon }}$ is the carbon conversion in the gasifier and, finally, $C_{\text {biomassdaf }}, H_{\text {biomassdaf }}, O_{\text {biomassdaf }}, S_{\text {biomassdaf }}, N_{\text {biomassdaf }}$ are the index for each component in the empirical formula of the switchgrass from the ultimate analysis of it presented in Table 1. The carbon conversion is limited to the interval between 0.87 and 0.98 according to the experimental results 6,7 .

The gasification agent (Air/Stream) is heated up before being fed to the gasifier. The inlet temperature is fixed to $673 \mathrm{~K}$. The particles leaving the gasifier are removed in a cyclone with an assumed efficiency of $99.99 \%$. 


\subsubsection{Digester}

The digester behaviour is described using the model proposed by León \& Martín ${ }^{9}$. The digester operates at $328 \mathrm{~K}$. The model requires experimental data for the treated biomass. The switchgrass properties for digestion are shown below ${ }^{10-13}$ :

$$
\begin{gathered}
0.289 \leq V_{\text {biogas } / S G}\left(m^{3} \text { biogas } / \mathrm{kg} S V\right) \leq 0.441 \\
0.367 \leq w_{D M / S G}(\mathrm{~kg} D M / \mathrm{kg}) \leq 0.508 \\
0.908 \leq w_{V S / S G}(\mathrm{~kg} V S / \mathrm{kg} D M) \leq 0.943 \\
89.8 \leq R_{C-N / S G} \leq 92.0 \\
0.00014 \leq w_{\text {Nam } / S G}^{\prime}\left(\mathrm{kg} N_{\text {am }} / \mathrm{kg} \mathrm{DM}\right) \leq 0.00108 \\
0.0018 \leq w_{\text {Norg } / S G}^{\prime}\left(\mathrm{kg} N_{\text {org }} / \mathrm{kg} \mathrm{DM}\right) \leq 0.0132 \\
0.0004 \leq w_{P / S G}^{\prime}(\mathrm{kg} P / \mathrm{kg} D M) \leq 0.0021 \\
0.0034 \leq w_{K / S G}^{\prime}(\mathrm{kg} \mathrm{K} / \mathrm{kg} \mathrm{DM}) \leq 0.0222
\end{gathered}
$$

The heat of combustion for the switchgrass is fixed to $17.4 \mathrm{MJ} / \mathrm{kg}$ dry biomass ${ }^{14}$.

\subsection{Gas Clean Up}

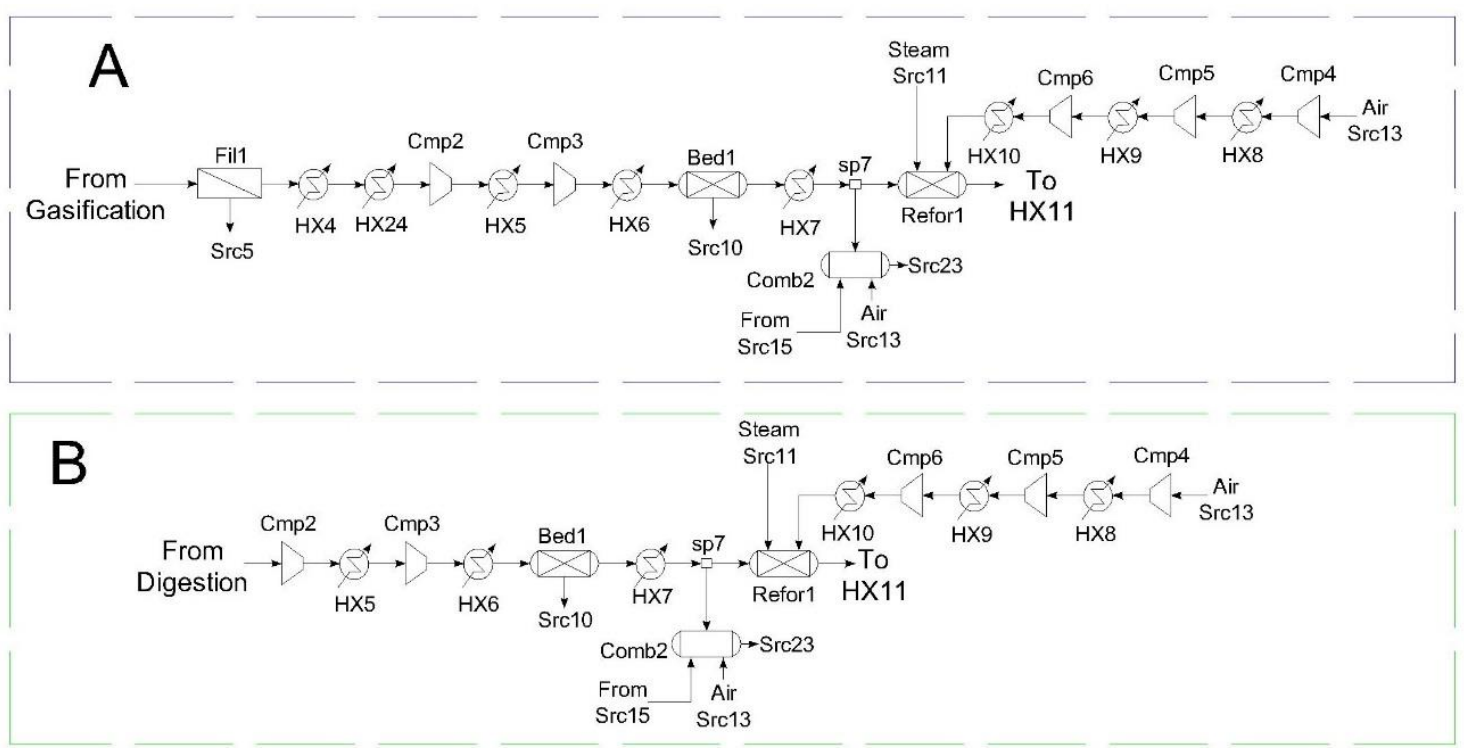


Figure S1: Gas Clean Up and Reformer Section: A: for gases from gasification, B: for gases from digestion.

The gas leaving the gasifier/digester section contains particles and hydrogen sulphide as main contaminants in the case of gasification (Figure S1-A) and only hydrogen sulphide in the case of biomass digestion (Figure S1-B). To remove particles and other small solids contained in the stream, a filter is used. After the filter, a train of compressors is employed to raise the pressure up to 2-3 $\mathrm{MPa}^{15,16}$. Intercooling between the compressors takes place to avoid a temperature too high between them improving the performance and reducing energy consumption ${ }^{17}$. The compressors are modelled as polytrophic with the following equations:

$$
\begin{gathered}
W=\frac{F \cdot 8.314 \cdot k \cdot\left(T_{\text {in }}+273.15\right)}{M W \cdot(k-1)}\left(\left(\frac{P_{\text {out }}}{P_{\text {in }}}\right)^{\frac{k-1}{k}}-1\right) \frac{1}{\eta_{s}} \\
T_{\text {out }}=T_{\text {in }}+\left(T_{\text {in }}+273.15\right)\left(\left(\frac{P_{\text {out }}}{P_{\text {in }}}\right)^{\frac{k-1}{k}}-1\right) \frac{1}{\eta_{s}}
\end{gathered}
$$

$\mathrm{T}$ is the temperature in ${ }^{\circ} \mathrm{C}, \mathrm{P}$ is the pressure in bar, $\eta_{s}$ is the efficiency fixed to 0.85 and $k$ is the polytrophic index equal to $1.4^{17}$.

The cooling between the compressors is modelled, as well as other heat exchanger included in this work, using mass and energy balances:

$$
\begin{gathered}
f c_{i}^{\text {in }}=f c_{i}^{\text {out }} \quad \forall i \\
Q=\sum_{i} f c_{i}^{\text {out }} h_{i}^{\text {out }}-\sum_{i} f c_{i}^{\text {in }} h_{i}^{\text {in }}
\end{gathered}
$$

Where $f c$ is the molar flowrate for each component $\mathrm{i}, h$ is the specific enthalpy per component and $\mathrm{Q}$ is the heat involved in the unit. The specific enthalpy is calculated as follows:

$$
h_{i}=\Delta H_{\text {form }, i}+\Delta H_{\mathrm{sen}, i}+\Delta H_{\text {latent }, i}
$$


Where $\Delta H_{\text {form }, i}$ is the heat of formation for component, $\Delta H_{\text {latent }, i}$ is the latent heat for component (if it is necessary in the stream involved) and $\Delta H_{\text {sen, } i}$ is the sensible heat for component. The sensible heat can include two terms: the liquid sensible heat and the gas sensible heat. In both cases, the sensible heat is computed as follows:

$$
\Delta H_{\mathrm{sen}, i}=\int_{T_{1}}^{T_{2}} C_{p, i}(T) \mathrm{dT}
$$

Where $C_{p, i}(T)$ is the heat capacity. In this work, the ideal behaviour is assumed and the heat capacity for the gases only depends on the temperature ${ }^{18,19}$. The relation between the heat capacity and the temperature follows the subsequent equation ${ }^{20}$ :

$$
C_{p, i}(T)=A_{i}+B_{i} \cdot T+C_{i} \cdot T^{2}+D_{i} \cdot T^{3}
$$

For the liquid, a constant value for the heat capacity is assumed.

To remove the hydrogen sulphide, the gas stream passes through a bed of $\mathrm{ZnO}$. Due to low sulphur content in biomass, it is possible to use this technology alone. A removal of $99.9 \%$ is considered ${ }^{21}$. Only $\mathrm{H}_{2} \mathrm{~S}$ is removal according to the following reaction:

$$
\mathrm{H}_{2} \mathrm{~S}+\mathrm{ZnO} \rightarrow \mathrm{H}_{2} \mathrm{O}+\mathrm{ZnS}
$$

A temperature of $473 \mathrm{~K}$ is fixed in the bed ${ }^{21}$. The removal takes place before the reformer due to the low sulphur tolerance of the ATR catalyst ${ }^{22}$.

\subsection{Reforming}

In the reforming stage, the methane and the rest of hydrocarbons are transformed into hydrogen, carbon monoxide, carbon dioxide and water. The objective is to increase the amount of hydrogen for the synthesis of ammonia.

Two kinds of reformers have been evaluated: Autothermal Reforming (ATR) and Steam Methane Reforming (SMR). In the first one, air and steam are introduced in the reformer. This one operates adiabatically and the heat necessary for the steam methane reforming reaction is supplied by the 
combustion with air of a fraction of the fed stream inside the reformer itself. The air used in the reformer is limited by the ratio between the nitrogen and hydrogen in the ammonia synthesis loop. The SMR only introduces steam and the heat necessary comes from the combustion with air of the outlet gases from the PSA system (Bed 2) in a separated chamber and, if it is necessary, a fraction of the gases generated in the gasifier/digester. In the reformer, the following reactions have been considered23:

$$
\begin{gathered}
\mathrm{C}_{n} \mathrm{H}_{m}+n \mathrm{H}_{2} \mathrm{O} \rightarrow n \mathrm{CO}+\left(n+\frac{m}{2}\right) \mathrm{H}_{2} \\
3 \mathrm{H}_{2}+\mathrm{CO} \rightleftarrows \mathrm{CH}_{4}+\mathrm{H}_{2} \mathrm{O} \\
\mathrm{CO}+\mathrm{H}_{2} \mathrm{O} \rightleftarrows \mathrm{H}_{2}+\mathrm{CO}_{2}
\end{gathered}
$$

In the first reaction, all high hydrocarbons are converted completely to carbon monoxide and hydrogen. Besides, two equilibria are involved, the decomposition of methane and the Water Gas Shift Reaction (WGSR). The reformer is modelled as an equilibrium reactor. The equilibrium constant for the two last reaction is taken from Roh et al. ${ }^{24}$ :

$$
\begin{gathered}
k_{p}=10^{\left(-\frac{11650}{T(K)}+13.076\right)}=\frac{P_{C O} P_{\mathrm{H}_{2}}^{3}}{P_{\mathrm{CH}_{4}} P_{\mathrm{H}_{2} \mathrm{O}}} \\
k_{p}=10^{\left(\frac{1910}{T(K)}-1.784\right)}=\frac{P_{\mathrm{CO}_{2}} P_{\mathrm{H}_{2}}}{P_{\mathrm{CO}} P_{\mathrm{H}_{2} \mathrm{O}}}
\end{gathered}
$$

The molar ratio between oxygen and methane in the ATR lies between 0.25 and 2. In SMR and ATR, the molar ratio between steam and methane could take a maximum value of $20^{25}$. The maximum temperature allowed in the reformer is fixed to $1600 \mathrm{~K}$.

The steam enters the reformer as saturated steam at the same pressure that the stream from the gasifier/digester. The air is compressed from the ambient up to the same pressure that the other two inlet streams in the reformer.

The mass and energy balances in the reformers are formulated as follows:

$$
f c_{C O}^{i n}+f c_{C_{2}}^{i n}+f_{C_{4}}^{i n}+n f c_{C_{n} H_{m}}^{i n}=f c_{C O}^{\text {out }}+f c_{C_{2}}^{o u t}+f c_{C_{4}}^{\text {out }}
$$




$$
2\left(f c_{H_{2} \mathrm{O}}^{i n}-n f_{C_{n} H_{m}}^{i n}\right)+4 f c_{C_{4}}^{i n}+2\left(f c_{H_{2}}^{\text {in }}+\left(n+\frac{m}{2}\right) f c_{C_{n} H_{m}}^{\text {in }}\right)+2 f c_{H_{2} \mathrm{O}}^{\text {steam }}+2 f c_{\mathrm{H}_{2} \mathrm{O}}^{\text {air }}=2 f c_{\mathrm{H}_{2} \mathrm{O}}^{\text {out }}+2 f c_{\mathrm{H}_{2}}^{\text {out }}+4 f c_{\mathrm{CH}_{4}}^{\text {out }}
$$

$$
\begin{gathered}
f c_{\mathrm{H}_{2} \mathrm{O}}^{\text {in }}+2 f c_{\mathrm{CO}_{2}}^{\text {in }}+\left(f c_{\mathrm{CO}}^{\text {in }}+n f c_{\mathrm{n}_{\mathrm{H}} \mathrm{H}_{m}}^{\text {in }}\right)+2 f c_{\mathrm{O}_{2}}^{\text {air }}+f c_{\mathrm{H}_{2} \mathrm{O}}^{\text {air }}+f c_{\mathrm{H}_{2} \mathrm{O}}^{\text {steam }}=f c_{\mathrm{H}_{2} \mathrm{O}}^{\text {out }}+2 f c_{\mathrm{CO}_{2}}^{\text {out }}+f c_{C O}^{\text {out }} \\
f c_{N_{2}}^{\text {in }}+f c_{N_{2}}^{\text {air }}=f c_{N_{2}}^{\text {out }} \\
\qquad c_{i}^{\text {in }}=f c_{i}^{\text {out }} \quad \forall i=\left\{N H_{3}, \mathrm{H}_{2} \mathrm{~S}, \text { Char, Ash, Olivine, } \mathrm{Ar}\right\} \\
y_{i}^{\text {out }}=\frac{f c_{i}^{\text {out }}}{\sum_{i} f c_{i}^{\text {out }}} \forall i \\
P_{i}^{\text {out }}=y_{i}^{\text {out }} P \\
\sum_{i} f c_{i}^{\text {in }} h_{i}^{\text {in }}+\sum_{i} f c_{i}^{\text {air }} h_{i}^{\text {air }}+\sum_{i} f c_{i}^{\text {steam }} h_{i}^{\text {steam }}=\sum_{i} f c_{i}^{\text {out }} h_{i}^{\text {out }}
\end{gathered}
$$

Where $f c$ is the molar flow for each specie $\mathrm{i}, y_{i}^{\text {out }}$ is the outlet molar fraction for each component $\mathrm{i}, P_{i}^{\text {out }}$ is the partial pressure in the outlet stream of the reformer, $P$ is the total pressure and $h_{i}$ is the enthalpy for each component.

\subsection{WGSR}

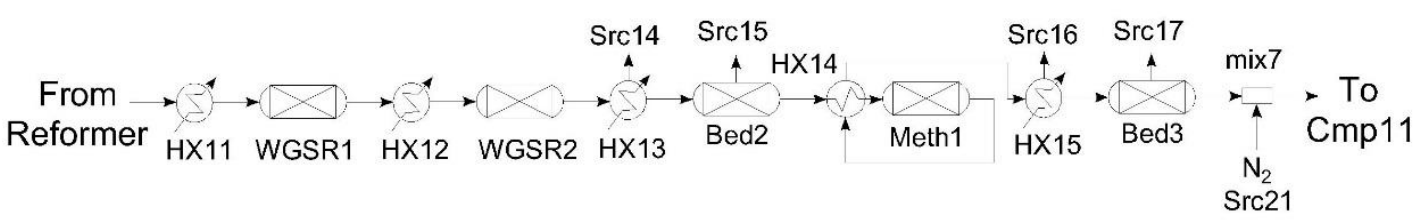

Figure S2: Shift reaction and methanator section

To reach the hydrogen content required for the synthesis of ammonia, the water gas shift reaction (WGSR) is employed (see Figure S2). With this, a reduction in the carbon monoxide concentration takes place, another factor interesting for the operation of the ammonia catalyst (see eq.(S37)). In this study, a two-step shift conversion is selected, one at high temperature and other at low temperature ${ }^{26}$. The first 
reactor (high temperature) has an outlet temperature in the range of $573-773 \mathrm{~K}$ and the second one (low temperature) between $453 \mathrm{~K}$ and $533 \mathrm{~K}^{26}$. Both reactors work as adiabatic. The WGSR reactors are modelled as an equilibrium system. For this purpose, the equation eq.(S39) is used. The heat exchangers before the reactors adapt the inlet temperature to achieve the desired outlet temperature.

The mass and energy balances for the WGS reactors are showed below:

$$
\begin{aligned}
& f c_{C O}^{i n}+f c_{\mathrm{CO}_{2}}^{\text {in }}=f c_{C O}^{\text {out }}+f c_{\mathrm{CO}_{2}}^{\text {out }} \\
& 2 f c_{\mathrm{H}_{2} \mathrm{O}}^{\text {in }}+2 f c_{\mathrm{H}_{2}}^{\text {in }}=2 f c_{\mathrm{H}_{2} \mathrm{O}}^{\text {out }}+2 f c_{\mathrm{H}_{2}}^{\text {out }} \\
& f c_{\mathrm{H}_{2} \mathrm{O}}^{\text {in }}+f c_{C O}^{\text {in }}+f c_{\mathrm{CO}_{2}}^{\text {in }}=f c_{\mathrm{H}_{2} \mathrm{O}}^{\text {out }}+f c_{C O}^{\text {out }}+f c_{C O_{2}}^{\text {out }} \\
& f c_{i}^{\text {in }}=f c_{i}^{\text {out }} \quad \forall i=\left\{\mathrm{CH}_{4}, \mathrm{NH}_{3}, \mathrm{~N}_{2}, \mathrm{H}_{2} \mathrm{~S}, \text { Char, Ash, Olivine, } \mathrm{Ar}\right\} \\
& y_{i}^{\text {out }}=\frac{f c_{i}^{\text {out }}}{\sum_{i} f c_{i}^{\text {out }}} \forall i \\
& P_{i}^{\text {out }}=y_{i}^{\text {out }} P \quad \forall i \\
& \sum_{i} f c_{i}^{\text {in }} h_{i}^{\text {in }}=\sum_{i} f c_{i}^{\text {out }} h_{i}^{\text {out }}
\end{aligned}
$$

\subsection{Final Syngas Adjust}

After the WGSR section, it is necessary to remove a large fraction of the following species present in the gas: methane, carbon dioxide and carbon monoxide, this last one due to the high poisoned effect on the ammonia catalyst and $\mathrm{CO}_{2}$ because of the production of carbonates.

First, in the Bed2 (see Figure S2), carbon dioxide is removed from the gases using activated carbon ${ }^{27}$. The PSA is designed to separate $100 \%$ of $\mathrm{CO}_{2}$. The other species are removed with different efficiencies according to their different adsorption kinetics (Table S4) ${ }^{27}$. The adsorption temperature is fixed to $343 \mathrm{~K}$. 
Table S4: Fraction of fed stream leaving the adsorption bed (Bed2)

\begin{tabular}{|c|c|}
\hline Component & $\begin{array}{c}\% \text { in the outlet stream (respect to } \\
\text { the initial amount) }\end{array}$ \\
\hline $\mathrm{H}_{2} \mathrm{O}$ & $0 \%$ \\
\hline $\mathrm{CO}_{2}$ & $0 \%$ \\
\hline $\mathrm{CH}_{4}$ & $45 \%$ \\
\hline $\mathrm{CO}$ & $75 \%$ \\
\hline $\mathrm{N}_{2}$ & $80 \%$ \\
\hline $\mathrm{H}_{2}$ & $97 \%$ \\
\hline
\end{tabular}

Due to the high sensitivity of the ammonia catalyst to carbon monoxide, it is necessary to reduce its concentration below 10ppm. To achieve this, the most appropriate method is methanation. In this process, the remained carbon monoxide is transformed into methane that is an inert using methanation. The equilibrium given by eq.(S36) is used. The final temperature in the methanator is limited between $523-623$ $\mathrm{K}$. Temperatures over $773 \mathrm{~K}$ must be avoided to prevent catalyst damage and below $473 \mathrm{~K}$ because of the risk of nickel carbonyl formation ${ }^{26}$. The equipment is modelled as an equilibrium and adiabatic reactor. The equilibrium constant is taken from equation eq.(S38). The mass and energy balances for this reactor are as follows:

$$
\begin{aligned}
& f c_{C O}^{\text {in }}+f c_{C H_{4}}^{\text {in }}=f c_{C O}^{\text {out }}+f c_{C_{4}}^{\text {out }} \\
& 2 f c_{\mathrm{H}_{2} \mathrm{O}}^{\text {in }}+2 f c_{\mathrm{H}_{2}}^{\text {in }}=2 f c_{\mathrm{H}_{2} \mathrm{O}}^{\text {out }}+2 f c_{\mathrm{H}_{2}}^{\text {out }} \\
& f c_{\mathrm{H}_{2} \mathrm{O}}^{\text {in }}+f c_{\mathrm{CO}}^{\text {in }}=f c_{\mathrm{H}_{2} \mathrm{O}}^{\text {out }}+f c_{\mathrm{CO}}^{\text {out }} \\
& f c_{i}^{\text {in }}=f c_{i}^{\text {out }} \quad \forall i=\left\{\mathrm{CO}_{2}, \mathrm{NH}_{3}, \mathrm{~N}_{2}, \mathrm{H}_{2} \mathrm{~S}, \text { Char, Ash, Olivine, } \mathrm{Ar}\right\} \\
& y_{i}^{\text {out }}=\frac{f c_{i}^{\text {out }}}{\sum_{i} f c_{i}^{\text {out }}} \forall i \\
& P_{i}^{\text {out }}=y_{i}^{\text {out }} P \quad \forall i
\end{aligned}
$$




$$
\sum_{i} f c_{i}^{i n} h_{i}^{i n}=\sum_{i} f c_{i}^{\text {out }} h_{i}^{\text {out }}
$$

After the methanator, the methane produced is separated using an activated carbon bed. The temperature is adjusted to $298 \mathrm{~K}$. The amounts of each component captured is shown in the Table S527.

Table S5: Fraction of fed stream leaving the adsorption bed (Bed3)

\begin{tabular}{|c|c|}
\hline Component & $\begin{array}{c}\% \text { in the outlet stream (respect to } \\
\text { the initial amount) }\end{array}$ \\
\hline $\mathrm{H}_{2} \mathrm{O}$ & $0 \%$ \\
\hline $\mathrm{CH}_{4}$ & $0 \%$ \\
\hline $\mathrm{CO}$ & $65 \%$ \\
\hline $\mathrm{N}_{2}$ & $80 \%$ \\
\hline $\mathrm{H}_{2}$ & $97 \%$ \\
\hline
\end{tabular}

\subsection{Ammonia Synthesis}

The compression of the inlet gas is the first step in the synthesis of ammonia (Figure 3). A multistage compression with intercooling is selected according to the rules of thumb ${ }^{17}$. The final pressure is limited within the range from 125 to 350 bar. After the compression, the inlet gases are fed to the synthesis loop. First at all, the inlet gases are mixed with the recycled gases in a mixer. At the outlet of this equipment, the ratio between hydrogen and nitrogen is limited in the interval of 3-3.2.

The reaction to synthetize the ammonia is shown below:

$$
\mathrm{N}_{2}+3 \mathrm{H}_{2} \rightleftarrows 2 \mathrm{NH}_{3}
$$

Two reactor designs have been considered: multibed reactor with direct cooling and multibed reactor with indirect cooling. The tubular design is not considered in this study because its use is limited to small scale production ${ }^{26}$. Here, only a summary of the modelling is described. The complete modelling of the ammonia reactor is found in Sánchez and Martín ${ }^{28}$. A three-bed reactor is used in both configurations.

Direct Cooling. In this reactor (Figure 3-A), the cooling between the beds, necessary to increase the conversion because of the tight equilibrium, takes places using a fraction of the fed stream. After mixing with the unreacted gases, the inlet stream is split in three fractions, one to each reactor bed. The inlet 
temperatures are around $673 \mathrm{~K}$ for each bed and final temperatures are limited in the range of $733-823 \mathrm{~K}$. A detailed model accounting for mass and energy balances, mass transfer, kinetic expressions, pressure drop, etc. is solved in MATLAB to provide bounds for the mass and energy balances used in the flowsheet optimization. Before mixing the fresh syngas with the gases leaving the reactor beds, each fraction of the inlet stream could be heated up using the outlet stream from the final bed.

Indirect Cooling. For this configuration (Figure 3-B), the cooling in the multibed reactor is carried out using external heat exchangers. The total flow passes through every bed. Due to the high temperature in the gases leaving the reactor beds, it is possible to generate steam. As in the previous reactor, a detailed model is used to set up the bounds for the optimization problem.

Ammonia is recovered by condensation after the reactor. A two stage cooling is carried out: A first step with water as cooling agent. The second one uses a refrigerant. In both cases, to determine the liquid fraction, a surrogate model is developed taking into account the main operating conditions involved (final pressure and temperature $)^{28}$.

In the cooling with water, the recovery yield to ammonia is given by:

$$
\beta_{\mathrm{NH}_{3}}=0.025860989+0.001428067 \cdot \frac{P(\mathrm{mmHg})}{760}
$$

In the second step with a refrigerant, the yields of each component follow these expressions:

$$
\begin{gathered}
\sigma_{\mathrm{NH}_{3}}=2.063269676+0.000163965 \cdot \frac{P(\mathrm{mmHg})}{760}-0.004908159 \mathrm{~T}(\mathrm{~K}) \\
\sigma_{\mathrm{H}_{2}}=-0.005616112+4.0769 \cdot 10^{-6} \cdot \frac{P(\mathrm{mmHg})}{760}+2.28468 \cdot 10^{-5} T(K) \\
\sigma_{N_{2}}=-0.008053425+9.08758 \cdot 10^{-6} \cdot \frac{P(\mathrm{mmHg})}{760}+3.49979 \cdot 10^{-5} T(K)
\end{gathered}
$$

In the gas stream leaving the gas-liquid separator, a purge is allowed to avoid impurities built-up. In the purge, a membrane to recover, mainly, hydrogen is installed because of the high value of this product. This membrane recovers $85 \%$ of hydrogen present in the initial stream and $10 \%$ of the other gases 29,30 . 


\section{Cost Estimation Procedure}

Using the results from the optimization, capital and operating costs have been estimated. The procedure for the estimation of the capital cost is based on the factorial methot ${ }^{20}$. To estimate the cost of equipment, the correlations presented in Almena and Martín ${ }^{31}$ have been employed. To evaluate the investment cost for the gasifier, the modified six-tenth rule is used (see Table S6). For the air/steam direct gasifier, it is assumed that the cost can be estimated with the same data as the oxygen/steam direct gasifier.

Table S6: Parameters to estimate the gasifier capital cost ${ }^{32}$

\begin{tabular}{|c|c|c|c|}
\hline Technology & Base Cost (MM\$) & Base Size (t dry biomass/h) & Scale factor \\
\hline Indirect gasifier & 16.3 & 68.8 & 0.65 \\
\hline $\mathrm{O}_{2}$ /Steam direct gasifier & 38.4 & 68.8 & 0.7 \\
\hline
\end{tabular}

For the digester, an organic loading rate of $15 \mathrm{~kg} \mathrm{VS} / \mathrm{m}^{3} \mathrm{~d}$ is fixed 33 and an estimated cost of $365 € / \mathrm{m}^{334,35}$. A normalized digester size of $6000 \mathrm{~m}^{3}$ has been considered ${ }^{34}$.

To estimate the investment cost of the reactors, the gas hourly space velocity (GHSV), the catalyst cost and the annual replacement are provided. With the GHSV, it is possible to calculate the volume of the reactor and, therefore, the catalyst amount. In Table S7, the value of these parameters for the following reactors is presented: ATR, SMR, WGSR and methanation reactor. The capital cost for the ammonia reactor is computed using the six-tenth rule ${ }^{36}$.

Table S7: Data for estimating reactors capital cost.

\begin{tabular}{|c|c|c|c|c|}
\hline & GHSV $\left(\mathrm{h}^{-1}\right)$ & $\begin{array}{c}\text { Catalyst Cost } \\
(\$ / \mathrm{kg})\end{array}$ & $\begin{array}{c}\text { Annual } \\
\text { Replacement }\end{array}$ & Source \\
\hline ATR & 1780 & 10.3 & $25 \%$ & $(37)$ \\
\hline SMR & 5000 & 25 & $15 \%$ & $(22)$ \\
\hline WGSR & 4000 & 22.3 & $50 \%$ & $(38)$ \\
\hline Methanation & 8000 & 21 & $0 \%$ & $(39)$ \\
\hline
\end{tabular}


For the adsorption bed, the estimation procedure is the same as in the previous reactors. For the $\mathrm{ZnO}$ bed, a GHSV of $10260 \mathrm{~h}^{-1}$ is assumed ${ }^{40}$. The cost is fixed equal to $355 \$ / \mathrm{ft}^{3} 38$ with an annual replacement. For the activated carbon beds, it is assumed an adsorbent price of $1 \$ / / b^{41}$.

For the production cost, the method proposed by Sinnott ${ }^{20}$ is employed. In this methodology, the production cost is computed as the sum of two terms: the variable and the fixed costs. In the variable costs, raw materials are included. The cost for the raw materials has been presented in the previous section. In the utilities item, the utilities cost has been computed following the same prices that in the objective function.

The fixed cost items include labour, amortization, insurances, taxes, maintenance and other items. The labour costs are computed using the correlation proposed by Couper et al. ${ }^{42}$. A summary table (Table S8) with the method to calculate the operating cost is presented.

Table S8: Summary of the operating cost calculations ${ }^{20}$

\begin{tabular}{|c|c|c|}
\hline \multicolumn{2}{|c|}{ Variable Costs } \\
\hline Raw materials & & from flowsheet optimization \\
\hline Miscellaneous materials & & $10 \%$ of Maintenance \\
\hline Utilities & & from flowsheet optimization \\
\hline & & \\
\hline & & \\
\hline Maintenance & & $5 \%$ of fixed capital \\
\hline Catalyst & & from previous estimation (Table S7) \\
\hline Labour & & $20 \%$ of Labour \\
\hline Laboratory & & $20 \%$ of Labour \\
\hline Supervision & & $50 \%$ of Labour \\
\hline Plant Overheads & & $10 \%$ of fixed capital \\
\hline Capital charges & & $1 \%$ of fixed capital \\
\hline Insurance & & $2 \%$ of fixed capital \\
\hline Taxes & &
\end{tabular}

\section{Nomenclature}

$a, b, c$ Coefficients for the indirect gasifier correlation (eq.(S1))

$a_{0-8}$ Coefficients for the Air/Steam direct gasifier correlation (eq.(S3)) 

$A, B, \mathrm{C}, \mathrm{D}, \mathrm{E}$ Coefficients for the $\mathrm{O}_{2} /$ Steam direct gasifier correlation (eq.(S2))
$C, H, O, S, N_{\text {biomass daf }}$ Index in the switchgrass empirical formula
$C_{p, i}$ Heat capacity per component $(\mathrm{kJ} / \mathrm{kmol} \cdot \mathrm{K})$
$E R$ Equivalent Ratio

$f_{i}$ Variables for the $\mathrm{O}_{2} /$ Steam direct gasifier correlation (eq.(S2))

$f c_{i}$ Molar flow for component i (kmol/s)

$h_{i}$ Specific enthalpy per component $\mathrm{i}(\mathrm{kJ} / \mathrm{kmol})$

$k_{p}$ Equilibrium constant

$k$ Polytrophic index

$M W_{i}$ Molecular weight for component I (kg/kmol)

$n_{j}^{\text {char }}$ Molar amount of component $\mathrm{j}$ in the char

$O P$ Oxygen Percentage of the enriched air

$P$ Pressure (bar)

$Q$ Heat $(\mathrm{kW})$

$P_{i}$ Partial pressure of component i (bar)

$R_{C-N / S G}$ Carbon to nitrogen ratio in the switchgrass (SG)

$S$ / $B$ Steam to Biomass Ratio

$T$ Temperature (K)

W Compressor power

$V_{\text {biogas } / S G}$ Biogas volume produced per mass unit of volatile solids (VS) in switchgrass (SG) (m³/kg)

$w_{D M / S G}$ Dry mass (DM) fraction in the switchgrass $(\mathrm{SG})(\mathrm{kg} / \mathrm{kg})$

$w_{V S / S G}$ Fraction of volatile solid (VS) with respect to dry mass of switchgrass (SG) $(\mathrm{kg} / \mathrm{kg}$ )

$w_{\text {Norg/SG }}^{\prime} N_{\text {org }}$ fraction in the dry mass of switchgrass (SG) $(\mathrm{kg} / \mathrm{kg})$

$w_{\mathrm{Nam} / \mathrm{SG}}^{\prime} \mathrm{N}_{\mathrm{am}}$ fraction in the dry mass of switchgrass $(\mathrm{SG})(\mathrm{kg} / \mathrm{kg})$

$w_{\mathrm{P} / S G}^{\prime} \mathrm{P}$ fraction in the dry mass of switchgrass $(\mathrm{SG})(\mathrm{kg} / \mathrm{kg})$

$w_{K / S G}^{\prime} \mathrm{K}$ fraction in the dry mass of switchgrass $(\mathrm{SG})(\mathrm{kg} / \mathrm{kg})$

$X$ Variables for the indirect gasifier correlation (eq.(S1)) 
$X_{\text {carbon }}$ Carbon conversion in the gasifier

$Y_{i}$ Yield in the Air/Steam direct gasifier $(\mathrm{g} / \mathrm{kg})$

$y_{i}$ Molar fraction of component $\mathrm{i}$

$\eta_{s}$ Compressor efficiency

$\beta_{\mathrm{NH}_{3}}$ Ammonia separation yield in the first heat exchanger $\mathrm{HX} 21$

$\sigma_{i}$ Separation yield for each component in the heat exchanger $\mathrm{HX} 22$

$\Delta H_{\text {form }, i}$ Heat of formation for component $(\mathrm{kJ} / \mathrm{kmol})$

$\Delta H_{\text {latent }, i}$ Latent heat for component $(\mathrm{kJ} / \mathrm{kmol})$

$\Delta H_{\text {sen, } i}$ Sensible heat for component $(\mathrm{kJ} / \mathrm{kmol})$

\section{References}

(1) Zhu, Y.; Gerber, M. A.; Jones, S. B.; Stevens, D. J. Analysis of the effects of compositional and configurational assumptions on product costs for the thermochemical conversion of lignocellulosic biomass to mixed alcohols. FY 2007 Progress Report. U.S. DOE. PNNL 17949, 2009.

(2) Phillips, S.; Aden, A.; Jechura, J.; Dayton, D.; Eggeman, T. Thermochemical ethanol via indirect gasification and mixed alcohol synthesis of lignocellulosic biomass. Technical Report, NREL/TP-51041168, April 2007.

(3) Martín, M.; Grossmann, I.E. Energy optimization of hydrogen production from biomass. Computers Chemical Engineering 2011, 35 (9), 1798-1806. DOI: 10.1016/j.compchemeng.2011.03.002.

(4) Di Blasi, C. Modeling wood gasification in a countercurrent fixed-bed reactor. AIChE Journal 2004, 50

(9), 2306-2319. DOI: 10.1002/aic.10189.

(5) Dutta, A.; Phillips, S.D. Thermochemical Ethanol via Direct Gasification and Mixed Alcohol Synthesis of Lignocellulosic Biomass. Technical Report, NREL/TP.510.45913, July 2009.

(6) Campoy, M.; Gómez-Barea, A.; Vidal, F.B.; Ollero, P. Air-Steam gasification of biomass in a fluidised bed: Process optimisation by enriched air. Fuel Processing Technology 2009, 90, 677-685. DOI: 10.1016/j.fuproc.2008.12.007.

(7) Campoy, M.; Gómez-Barea, A.; Villanueva, A.L.; Ollero, P. Air-Steam Gasification of Biomass in a Fluidized Bed under Simulated Autothermal and Adiabatic Conditions. Ind. Eng. Chem. Res. 2008, 47, 5957-5965. DOI: 10.1021/ie800220t.

(8) Thunman, H.; Niklasson, F.; Johnsson, F.; Leckner, B. Composition of Volatile Gases and Thermochemical Properties of Wood for Modeling of Fixed or Fluidized Beds. Energy \& Fuels 2001, 15, 1488-1497. DOI: 10.1021/ef010097q.

(9) León, E.; Martín, M. Optimal production of power in a combined cycle from manure based biogas. Energy Conversion and Management 2016, 114, 89-99. DOI: 10.1016/j.enconman.2016.02.002. 
(10) Massé, D.; Gilbert, Y.; Savoie, P.; Bélanger, G.; Parent, G.; Babineau, D. Methane yield from switchgrass and reed canarygrass grown in Eastern Canada. Bioresource Technology 2011, 102, 1028610292. DOI: 10.1016/j.biortech.2011.08.087.

(11) Frigon, J.C.; Mehta, P.; Guiot, S.R. Impact of mechanical, chemical and enzymatic pre-treatments on the methane yield from the anaerobic digestion of switchgrass. Biomass and Bioenergy 2012, 36, 1-11. DOI: 10.1016/j.biombioe.2011.02.013.

(12) Paul, S.; Dutta, A. Challenges and opportunities of lignocellulosic biomass for anaerobic digestion. Resources, Conservation \& Recycling 2018, 130, 164-174. DOI: 10.1016/j.resconrec.2017.12.005.

(13) Brown, D.; Shi, J.; Li, Y. Comparison of solid-state to liquid anaerobic digestion of lignocellulosic feedstocks for biogas production. Bioresource Technology 2012, 124, 379-386. DOI: 10.1016/j.biortech.2012.08.051.

(14) Monti, A. Switchgrass: A Valuable Biomass Crop for Energy. Springer, 2012. DOI: 10.1007/978-14471-2903-5.

(15) Reimert, R.; Friedemann, M.; Renner, H.J.; Boll, W.; Supp, E.; Brejc, M.; Liebner, W.; Schaub, G. Gas Production, 2 Processes. Ullmann's Encyclopedia of Industrial Chemistry 2011. DOI: 10.1002/14356007.012_001.

(16) Gupta, R.M. Hydrogen Fuel. Production, Transport and Storage. CRC Press, 2009.

(17) Couper, J.R.; Penney, W.R.; Fair, J.R.; Walas, S.M. Chemical Process Equipment. Selection and Design. Second Edition. Gulf Professional Publishing. Elsevier, 2005. DOI: 10.1016/C2011-0-08248-0.

(18) Smith, J.M.; Van Ness, H.C.; Abbott, M.M. Introduction to Chemical Engineering Thermodynamics. Seventh Edition. Mc Graw Hill, 2004.

(19) Çengel, Y.A.; Boles, M.A. Thermodynamics. An Engineering Approach. Eighth Edition. Mc Graw Hill, 2011.

(20) Sinnott, R.K. Chemical Engineering Design. Coulson \& Richardson's Chemical Engineering Series. Volume 6. Elsevier, 2005. DOI: 10.1016/C2009-0-11215-1.

(21) Shah, Y.T. Energy and Fuel Systems Integration. CRC Press, 2016.

(22) Reyes Valle, C.; Villanueva Perales, A.L.; Vidal-Barrero, F.; Gómez-Barea, A. Techno-economic assessment of biomass-to-ethanol by indirect fluidized bed gasification: Impact of reforming technologies and comparison with entrained flow gasification. Applied Energy 2013, 109, 254-266. DOI: 10.1016/j.apenergy.2013.04.024.

(23) Aasberg-Petersen, K.; Christensen, T.S.; Stub Nielsen, C.; Dybkjaer, I. Recent developments in autothermal reforming and pre-reforming for synthesis gas production in GTL applications. Fuel Processing Technology 2013, 83, 253-261. DOI: 10.1016/S0378-3820(03)00073-0.

(24) Roh, H.S.; Lee, D.K.; Koo, K.Y.; Jung, U.H.; Yoon, W.L. (2010). Natural gas steam reforming for hydrogen production over metal monolith catalyst with efficient heat-transfer. International Journal of Hydrogen Energy 2010, 35, 1613-1619. DOI: 10.1016/j.jijhydene.2009.12.051.

(25) Chen, W.H.; Lin, M.R.; Lu, J.J.; Chao, Y.; Leu, T.S. Thermodynamic analysis of hydrogen production from methane via autothermal reforming and partial oxidation followed by water gas shift reaction. 
International Journal of Hydrogen Energy 2010, 35(21), 11787-11797. DOI: 10.1016/j.jijhydene.2010.08.126.

(26) Appl, M. Ammonia: Principles and Industrial Practice. Wiley-VCH, 1999. DOI: 10.1002/9783527613885.

(27) Lopes, F.V.S.; Grande, C.A.; Ribeiro, A.M.; Loureiro, J.M.; Evaggelos, O.; Nikolakis, V.; Rodrigues, A.E. Adsorption of $\mathrm{H}_{2}, \mathrm{CO}_{2}, \mathrm{CH}_{4}, \mathrm{CO}, \mathrm{N}_{2}$ and $\mathrm{H}_{2} \mathrm{O}$ in Activated Carbon and Zeolite for Hydrogen Production. Separation Science and Technology 2009, 44(5), 1045-1073. DOI: 10.1080/01496390902729130.

(28) Sánchez, A.; Martín, M. Optimal renewable production of ammonia from water and air. Journal of Cleaner Production 2018, 178, 325-342. DOI: 10.1016/j.jclepro.2017.12.279.

(29) Air Products. PRISM® Membrane Systems for Ammonia plants... Tell Me More. 2016. http://www.airproducts.no/wp-content/uploads/2016/06/Membrane-Systems-For-Ammonia-Plants.pdf Last accessed: September, 2018.

(30) Membrane Technology and Research. Hydrogen Recovery from Ammonia Plant Purge Gas. 2016. http://www.mtrinc.com/pdf_print/refinery_and_syngas/MTR_Brochure_Hydrogen_Recovery_from_Ammoni a_Plant_Purge_Gas.pdf. Last accessed: September, 2018.

(31) Almena, A.; Martín, M. Technoeconomic Analysis of the Production of Epichlorohydrin from Glycerol. Industrial \& Engineering Chemistry Research 2016, 55(12), 3226-3238. DOI: 10.1021/acs.iecr.5b02555.

(32) Sadhukhan, J.; Ng, K.S.; Hernandez, E.M. Biorefineries and chemical processes: Design, integration and sustainability analysis. John Wiley \& Sons, 2014. DOI: 10.1002/9781118698129.

(33) Brebbia, C.A. The Sustainable World. WIT press, 2011.

(34) Taifouris, M. R.; Martín, M. Multiscale scheme for the optimal use of residues for the production of biogas across Castile and Leon. Journal of Cleaner Production 2018, 185, 239-251. DOI: 10.1016/j.jclepro.2018.03.018.

(35) Doddapaneni, T.R.K.C.; Praveenkumar, R.; Tolvanen, H.; Rintala, J.; Konttinen, J. Techno-economic evaluation of integrating torrefaction with anaerobic digestion. Applied Energy 2018, 213, 272-284. DOI: 10.1016/j.apenergy.2018.01.045.

(36) Morgan, E.R. Techno-Economic Feasibility Study of Ammonia Plants Powered by Offshore Wind. Dissertations. Paper 697, 2013.

(37) Villanueva-Perales, A.L.; Reyes-Valle C.; Ollero, P.; Gómez-Barea, A. Technoeconomic assessment of ethanol production via thermochemical conversion of biomass by entrained flow gasification. Energy 2011, 36, 4097-4108. DOI: 10.1016/j.energy.2011.04.037.

(38) Nexant. Equipment Design and Cost Estimation for Small Modular Biomass Systems, Synthesis Gas Cleanup, and Oxygen Separation Equipment. Task 2: Gas Cleanup Design and Cost Estimates -Wood Feedstock, 2006.

(39) Bartholomew, C.H.; Farrauto, R.J. Fundamentals of Industrial Catalytic Processes. WileyInterscience, Second Edition, 2006. DOI: 10.1002/9780471730071. 
(40) Hofbauer, H.; Rauch, R.; Ripsfel-Nitsche, K. Report on Gas Cleaning for Synthesis Applications. Work Package 2E: "Gas treatment", 2007.

(41) EPA. EPA Air Pollution Control Cost Manual. Sixth Edition, 2002.

(42) Couper, J. R.; Hertz, D.W.; Smith, F.L. Perry's Chemical Engineers Handbook. $8^{\text {th }}$ edition. Mc Graw Hill, 2008. DOI: 10.1036/0071422943. 